\title{
PENGARUH KINERJA KEUANGAN DAERAH TERHADAP IPM KABUPATEN/KOTA DI JAWA BARAT
}

\author{
Hamimah Hamimah ${ }^{1}$, Zulkarnain Zulkarnain ${ }^{2}$ \\ 1,2 Program Studi Akuntansi, Institut Manajemen Wiyata Indonesia Email Korespondensi: \\ zulkarnain@imwi.ac.id
}

\begin{abstract}
Abstrak
Penguatan SDM Indonesia menuju SDM unggul menjadi pekerjaan rumah besar Negara dan seluruh bangsa Indonesia. Kualitas SDM Indonesia dipandang masih rendah. Penelitian ini berupaya untuk menguji pengaruh kinerja keuangan daerah yang diproksikan dengan rasio derajat desentralisasi fiskal, rasio efektivitas PAD, dan rasio belanja modal terhadap IPM kabupaten/ kota di Jawa Barat. Metode penelitian yang digunakan adalah dengan pendekatan kuantitatif. Pengujian hipotesis dilakukan dengan menggunakan uji regresi linier berganda melalui alat bantu SPSS ver. 26. Hasil pengujian dan analisis data menemukan bahwa secara parsial rasio derajat desentralisasi fiskal dan rasio efektivitas PAD berpengaruh positif dan signifikan terhadap IPM. Sedangkan rasio belanja modal tidak berpengaruh signifikan terhadap IPM. Secara simultan ketiga variabel independen memiliki kemampuan menjelaskan variasi variabel dependen yaitu IPM sebesar 57,0\%, sedangkan sisanya 43,0\% dijelaskan atau dipengaruhi oleh faktor lain di luar variabel penelitian yang digunakan.
\end{abstract}

Kata Kunci: IPM, Rasio Derajat Desentralisasi Fiskal, Rasio Efektivitas PAD, Rasio Belanja Modal

\begin{abstract}
Strengthening Indonesian human resources towards superior human resources is the big homework of the State and the entire Indonesian nation. The quality of Indonesian human resources is still considered low. This study seeks to examine the effect of regional financial performance as proxied by the degree of fiscal decentralization ratio, the PAD effectiveness ratio, and the capital expenditures ratio to the HDI of districts /cities in West Java. The research method used is a quantitative approach. Hypothesis testing is done by using multiple linear regression through the SPSS ver. 26. The results of testing and data analysis found that partially the degree of fiscal decentralization ratio and the PAD effectiveness ratio had a positive and significant effect on HDI. Meanwhile, the capital expenditure ratio has no significant effect on HDI. Simultaneously, the three independent variables have the ability to explain variations in the dependent variable, namely the HDI of $57.0 \%$, while the remaining $43.0 \%$ is explained or influenced by other factors outside the research variables used.
\end{abstract}

Keywords: HDI, Degree of Fiscal Decentralization Ratio, PAD Effectiveness Ratio, Capital Expenditures Ratio

\section{PENDAHULUAN}

Dunia masa kini berubahnya sangat cepat. Perubahan ini menghadirkan kejutan-kejutan. Suatu kemapanan bisa saja sewaktu-waktu runtuh, sedangkan ketidakmungkinan bisa saja terjadi. Cara lama yang sudah teruji bisa membawa pada sebuah kesuksesan bisa tiba-tiba usang, digantikan oleh cara baru yang lebih gemilang dan mengagumkan. Presiden Jokowi pada sebuah kesempatan menyampaikan kondisi seperti ini harus disikapi dengan perubahan secara masif pada kapabilitas diri sendiri dan/atau organisasi, adalah penting untuk memaksimalkan potensi, begitu pula inovasi, dan kecepatan beradaptasi dengan disrupsi (Asmara, 2019).

Penguatan SDM Indonesia menuju SDM unggul menjadi pekerjaan rumah besar Negara dan 


\section{REKAN}

Riset Ekonami. Akeuntansi dan Perpajakan
Vol 1 No. 2 September 2020

e-ISSN : 2721-4109

seluruh bangsa Indonesia. Data dari Bank Dunia pada tahun 2018 menyebutkan kualitas SDM Indonesia masih rendah, yaitu menduduki peringkat ke- 87 dari sejumlah 157 negara. Business World pada tahun yang sama memeringkatkan daya saing bangsa-bangsa di dunia, dan SDM Indonesia berada di peringkat ke- 45 dari 63 negara. Peringkat ini di bawah dua negara tetangga yakni Singapura dan Malaysia dimana masing- masing berada di peringkat 13 dan 22 (Sugiarto, 2019).

Komitmen Pemerintahan Presiden Jokowi untuk menguatkan SDM Indonesia melalui penganggaran tercermin dengan peningkatan alokasi anggaran untuk pembangunan kualitas manusia, terus bergerak naik di tengah keterbatasan keuangan Negara. Dalam APBN 2018, alokasi anggaran untuk pendidikan mencapai Rp147,56 triliun, kesehatan Rp65,01 triliun, dan perlindungan sosial Rp162,56 triliun (Sugiarto, 2019).

BPS mencatat Indeks Pembangunan Manusia (IPM) Indonesia pada tahun 2019 sebesar 71,92, yang lebih tinggi dari IPM pada tahun 2018 sebesar 71,39. Kenaikan IPM ini selaras dengan perbaikan kualitas pendidikan, angka harapan hidup, dan daya beli masyarakat. Berdasarkan provinsi, DKI Jakarta pada tahun 2019 memiliki IPM paling tinggi, di atas 80, dengan angka sebesar 80,76. Sementara mayoritas provinsi lain di Indonesia berada pada status tinggi, pada kisaran IPM dari 70 hingga kurang dari 80 (Lidwina \& Fitra, 2020). Bila diturunkan sampai ke kota/kabupaten, di beberapa daerah masih terdapat pula IPM yang sedang dan rendah. Pemerintah, baik pusat maupun daerah memiliki tugas untuk mempersempit disparitas IPM antar daerah yang masih lebar (Tusin \& Hidayat, 2020).

Provinsi Jawa Barat (sebagai lokasi penelitian) pada tahun 2019 secara nasional berada di peringkat ke sepuluh dengan angka IPM sebesar 72,03. Bila dijabarkan peringkat IPM sampai ke 27 kabupaten/kota di Jawa Barat sebagai berikut:

Tabel 1

IPM Kabupaten/Kota di Jawa Barat Tahun 2019 \& 2018

\begin{tabular}{lllrr}
\hline \multirow{2}{*}{ No. Nama Pemerintah Daerah } & & IPM & No18 & Naik/Turun \\
\cline { 3 - 5 } & & $\mathbf{2 0 1 9}$ & 81.06 & 0.56 \\
\hline 1 & Kota Bandung & 81.62 & 81.04 & 0.55 \\
\hline 2 & Kota Bekasi & 80.82 & 80.29 & 0.53 \\
\hline 3 & Kota Depok & 78.11 & 77.56 & 0.55 \\
\hline 4 & Kota Cimahi & 76.23 & 75.66 & 0.57 \\
\hline 5 & Kota Bogor & 74.92 & 74.35 & 0.57 \\
\hline 6 & Kota Cirebon & 74.31 & 73.55 & 0.76 \\
\hline 7 & Kota Sukabumi & 73.99 & 73.49 & 0.50 \\
\hline 8 & Kab. Bekasi & 72.84 & 72.03 & 0.81 \\
\hline 9 & Kota Tasikmalaya & 72.41 & 71.75 & 0.66 \\
\hline 10 & Kab. Bandung & 71.75 & 71.25 & 0.50 \\
\hline 11 & Kota Banjar & 71.46 & 70.99 & 0.47 \\
\hline 12 & Kab. Sumedang & 70.86 & 69.89 & 0.97 \\
\hline 13 & Kab. Karawang & 70.67 & 69.98 & 0.69 \\
\hline 14 & Kab. Purwakarta & 70.65 & 69.69 & 0.96 \\
\hline 15 & Kab. Bogor & 70.39 & 69.63 & 0.76 \\
\hline 16 & Kab. Ciamis & 69.12 & 68.55 & 0.57 \\
\hline 17 & Kab. Kuningan & 68.69 & 68.05 & 0.64 \\
\hline 18 & Kab. Cirebon & 68.69 & 68.31 & 0.38 \\
\hline 19 & Kab. Subang & 68.27 & 67.46 & 0.81 \\
\hline 20 & Kab. Bandung Barat & 68.21 & 67.44 & 0.77 \\
\hline 21 & Kab. Pangandaran & 67.52 & 66.72 & 0.80 \\
\hline 22 & Kab. Majalengka & 66.97 & 66.36 & 0.61 \\
\hline 23 & Kab. Indramayu & 66.87 & 66.05 & 0.82 \\
\hline 24 & Kab. Sukabumi & 66.22 & 65.42 & 0.80 \\
\hline 25 & Kab. Garut & 65.64 & 65.00 & 0.64 \\
\hline 26 & Kab. Tasikmalaya & 65.38 & 64.62 & 0.76 \\
\hline 27 & Kab. Cianjur & & & \\
\hline
\end{tabular}

Sumber: BPS (2020)

Tabel 1 di atas menunjukkan terjadinya disparitas yang cukup lebar di antara pemerintah daerah dengan IPM tertinggi dan terendah di Jawa Barat. Kota Bandung di peringkat pertama bahkan dengan IPM yang lebih tinggi dari Provinsi DKI Jakarta, sedangkan Kabupaten Cianjur di peringkat akhir mendekati IPM Provinsi Papua sebagai provinsi dengan IPM paling rendah (Lidwina \& Fitra, 2020). 
Sebuah data dari penelitian oleh Zulkarnain (2020) yang meneliti tentang kinerja keuangan pemerintah kabupaten/kota di Jawa Barat tahun 2014-2018 menunjukkan bahwa Kota Bandung (sebagai daerah dengan IPM tertinggi) memiliki kinerja keuangan tertinggi dari segi rasio derajat desentralisasi fiskal. Sedangkan Kabupaten Tasikmalaya (sebagai daerah dengan IPM terendah kedua) memiliki kinerja keuangan terendah dari segi rasio derajat desentralisasi fiskal. Hal tersebut memunculkan pertanyaan, apakah kinerja keuangan daerah berkontribusi atau memiliki pengaruh terhadap IPM?

Penelitian oleh Harliyani \& Haryadi (2016) di Provinsi Jambi menemukan bahwa kinerja keuangan pemerintah daerah dapat memberi pengaruh pada peningkatan IPM. Kinerja keuangan yang baik berimbas pada kemampuan daerah untuk memberikan layanan yang baik pula sehingga dapat meningkatkan IPM. Penelitian ini berupaya untuk menguji adakah pengaruh kinerja keuangan daerah yang diproksikan dengan rasio derajat desentralisasi fiskal, rasio efektivitas $\mathrm{PAD}$, dan rasio belanja modal terhadap IPM. Dalam hal ini pada pemerintahan daerah kabupaten/kota di Jawa Barat. Melalui penelitian ini diharapkan dapat disajikan informasi penting terkait kinerja keuangan daerah dan pengaruhnya, dimana informasi tersebut yang dapat memengaruhi proses pengambilan keputusan di daerah memang perlu diungkapkan secara penuh (Zulkarnain \& Andriansyah, 2018).

\section{PENGEMBANGAN HIPOTESIS}

\section{Rasio Derajat Desentralisasi Fiskal dan IPM}

Rasio derajat desentralisasi fiskal adalah proksi pertama dari kinerja keuangan daerah pada penelitian ini, yang dapat dihitung dengan memproporsikan total realisasi PAD terhadap total realisasi Pendapatan Daerah. Dari rasio ini secara tidak langsung mengambarkan kemampuan pemerintah daerah mengumpulkan PAD hingga dapat digunakan untuk membiayai pembangunan di daerah (Mahmudi, 2016). Pembangunan dimaksud dapat berupa peningkatan layanan publik, yang bila layanan publik tersebut meningkat dan semakin baik diharapkan dapat meningkatkan kualitas hidup dan kesejahteraan masyarakat. Kualitas hidup atau standar hidup yang layak merupakan salah satu indikator IPM. Penelitian oleh Harliyani \& Haryadi (2016), Widyatama (2017), dan Hudaya (2019) menemukan bahwa rasio derajat desentralisasi fiskal berpengaruh positif terhadap IPM. Atas dasar itu diajukan hipotesis pertama untuk penelitian ini sebagai berikut:

\section{$\mathrm{Ha}_{1}$ : Rasio Derajat Desentralisasi Fiskal berpengaruh positif terhadap IPM}

\section{Rasio Efektivitas PAD dan IPM}

Rasio efektivitas PAD adalah proksi kedua dari kinerja keuangan daerah pada penelitian ini, yang dapat dihitung dengan membandingkan realisasi penerimaan PAD dan anggaran PAD, menunjukkan kemampuan pemerintah daerah untuk merealisasikan target anggaran PAD (Mahmudi, 2016). Keberhasilan daerah dengan efektif merealisasikan target anggaran PAD dapat dikaitkan dengan sesuainya kondisi perekonomian daerah pada saat itu dengan pada saat penyusunan anggaran PAD, ataupun pula terjadi peningkatan dalam perekonomian daerah, yang berimbas pada peningkatan kesejahteraan masyarakat.

Penelitian oleh Prakoso (2017), Widyatama (2017), dan Hanif (2019) menemukan bahwa rasio efektivitas PAD berpengaruh positif terhadap IPM. Atas dasar itu diajukan hipotesis kedua untuk penelitian ini sebagai berikut:

\section{$\mathrm{Ha}_{2}$ : Rasio Efektivitas PAD berpengaruh positif terhadap IPM}

\section{Rasio Belanja Modal dan IPM}

Rasio belanja modal adalah proksi ketiga dari kinerja keuangan daerah pada penelitian ini, yang dapat dihitung dengan membandingkan total belanja modal dengan belanja daerah secara keseluruhan (Mahmudi, 2016). Belanja modal merupakan bagian dari belanja daerah yang dikeluarkan untuk perolehan aset tetap atau aset lainnya yang dapat berupa pembangunan jalan, bangunan, maupun infrastruktur publik lainnya sehingga dapat memaksimalkan pelayanan sektor publik secara berkesinambungan, hingga diharap- kan dapat meningkatkan kualitas hidup, standar hidup layak, dan kesejahteraan masyarakat. 


\section{REKAN}

Riset Ekanomi. Akuntansi dan Perpajakan
Vol 1 No. 2 September 2020

e-ISSN : 2721-4109

Penelitian oleh Sari \& Supadmi (2016), Umiyati et al. (2017), dan Tarumingkeng et al. (2019) menemukan bahwa rasio belanja modal berpengaruh positif terhadap IPM. Atas dasar itu diajukan hipotesis ketiga untuk penelitian ini sebagai berikut:

\section{Ha 3 : Rasio Belanja Modal berpengaruh positif terhadap IPM}

\section{METODOLOGI}

Penelitian ini termasuk jenis penelitian kuantitatif. Jenis data yang digunakan adalah data sekunder. Subjek penelitian adalah pemerintah kabupaten/kota di Jawa Barat. Penelitian ini bertujuan untuk menguji pengaruh kinerja keuangan daerah yang diproksikan dengan rasio derajat desentralisasi fiskal $\left(\mathrm{X}_{1}\right)$, rasio efektivitas PAD $\left(\mathrm{X}_{2}\right)$, dan rasio belanja modal $\left(\mathrm{X}_{3}\right)$ terhadap IPM $(\mathrm{Y})$. Periode dari kinerja keuangan daerah dan IPM yang diamati adalah periode tahun 2014-2018.

Data mengenai IPM bersumber dari terbitan "Provinsi Jawa Barat dalam Angka tahun 2020" dari Badan Pusat Statistik Provinsi Jawa Barat (BPS Jabar, 2020). Sedangkan data mengenai rasio derajat desentralisasi fiskal, rasio efektivitas PAD, dan rasio belanja modal bersumber dari data penelitian oleh Zulkarnain (2020) yang dipublikasikan di Jurnal Cakrawala 3(1) dengan judul "Analisis Rasio Keuangan Daerah untuk Mengukur Kinerja Keuangan Pemerintah Kabupaten/Kota di Jawa Barat".

Pengujian hipotesis dilakukan dengan menggunakan uji regresi linier berganda melalui alat bantu SPSS ver. 26. Diantara hasil yang akan disajikan dalam bagian hasil dan pembahasan adalah hasil statistik deskriptif, hasil uji regresi linier berganda, hasil uji statistik t, uji statistik $\mathrm{F}$, dan koefisian determinasi.

\section{HASIL DAN PEMBAHASAN}

Hasil Statistik Deskriptif

Tabel 2

Hasil Statistik Deskriptif

\begin{tabular}{|c|c|c|c|c|c|c|}
\hline Variabel & $\mathrm{N}$ & Mi & num & Maximum & Mean & $\begin{array}{l}\text { Std. } \\
\text { Deviation }\end{array}$ \\
\hline IPM & & 135 & 62.08 & 81.06 & 69.73 & 4.9581 \\
\hline Rasio DDF & & 135 & 0.0501 & 0.4631 & 0.2137 & 0.1094 \\
\hline Rasio Efektivitas PAD & & 135 & 0.5017 & 1.9031 & 1.1575 & 0.2434 \\
\hline Rasio Belanja Modal & & 135 & 0.0884 & 0.3697 & 0.1994 & 0.0548 \\
\hline
\end{tabular}

Sumber: Hasil Olah Data SPSS (2020)

Tabel 2 di atas menunjukkan IPM terendah sebesar 62,08, yang terjadi pada Kabupaten Cianjur pada tahun 2014 dan tertinggi sebesar 81,06, yang terjadi pada Kota Bandung pada tahun 2018. Nilai rata-rata IPM sebesar 69,73. Pada tahun 2018 sebanyak 14 kabupaten/kota yang memiliki IPM di atas nilai rata-rata tersebut dan sebanyak 13 kabupaten/kota yang memiliki IPM di bawah nilai rata-rata tersebut. Lima besar kabupaten/kota yang memiliki IPM di atas rata-rata pada tahun 2018 diantaranya Kota Bandung $(81,06)$, Kota Bekasi $(81,04)$, Kota Depok $(80,29)$, Kota Cimahi $(77,56)$, dan Kota Bogor $(75,66)$.

Tabel 2 di atas juga menunjukkan nilai rasio derajat desentralisasi fiskal terendah sebesar 5,01\%, yang terjadi pada Kabupaten Pangandaran pada tahun 2014 dan tertinggi sebesar 46,31\%, yang terjadi pada Kabupaten Bekasi pada tahun 2017. Nilai rata-rata rasio DDF sebesar 21,37\%. Pada tahun 2018 sebanyak 10 kabupaten/kota yang memiliki nilai rasio DDF di atas nilai rata-rata tersebut dan sebanyak 17 kabupaten/ kota yang memiliki nilai rasio DDF di bawah nilai rata-rata tersebut. Lima besar kabupaten/kota yang memiliki rasio DDF di atas rata-rata pada tahun 2018 diantaranya Kota Bandung (43,29), Kota Bekasi $(41,38)$, Kabupaten Bekasi $(40,32)$, Kota Bogor $(39,17)$, dan Kabupaten 


\section{Bogor (38,28).}

Selanjutnya, nilai rasio efektivitas PAD terendah sebesar 50,17\%, yang terjadi pada Kabupaten Purwakarta pada tahun 2016 dan tertinggi sebesar 190,31\%, yang terjadi pada Kabupaten Tasikmalaya pada tahun 2017. Lima besar kabupaten/kota yang memiliki rasio efektivitas PAD tertinggi pada tahun 2018 diantaranya Kabupaten Bogor (119,01), Kabupaten Cirebon (116,50), Kabupaten Bandung (114,01), Kabupaten Bandung Barat (113,47), dan Kabupaten Ciamis (109,00).

Nilai rasio belanja modal terendah sebesar $8,84 \%$, yang terjadi pada Kabupaten Kuningan pada tahun 2018 dan tertinggi sebesar 36,97\%, yang terjadi pada Kota Depok pada tahun 2016. Lima besar kabupaten/kota yang memiliki rasio belanja modal tertinggi pada tahun 2018 diantaranya Kota Depok $(27,86)$, Kabupaten Pangandaran (24,53), Kabupaten Majalengka (24,41), Kota Banjar $(24,10)$, dan Kabupaten Indramayu $(23,69)$.

\section{Hasil Uji Regresi Linier Berganda \\ Tabel 3 \\ Hasil Uji Regresi Linier Berganda}

\begin{tabular}{|c|c|c|c|c|}
\hline Variabel Independen & Beta & $\mathrm{t}$ & Sig. & Keterangan \\
\hline Rasio DDF $\left(\mathrm{X}_{1}\right)$ & 32.022 & 11.970 & 0.000 & Signifikan \\
\hline Rasio Efektivitas PAD $\left(\mathrm{X}_{2}\right)$ & 3.445 & 2.971 & 0.004 & Signifikan \\
\hline Rasio Belanja Modal $\left(\mathrm{X}_{3}\right)$ & 5.604 & 1.053 & 0.294 & $\begin{array}{l}\text { Tidak } \\
\text { Signifikan }\end{array}$ \\
\hline F Hitung & 60.234 & & & \\
\hline F Sig. & 0.000 & & & \\
\hline Adjusted R Square & 0.570 & & & \\
\hline
\end{tabular}

Berdasarkan hasil uji regresi linier berganda pada tabel 3, pengaruh variabel independen $\left(\mathrm{X}_{1}, \mathrm{X}_{2}\right.$, $\mathrm{X}_{3}$ ) secara parsial terhadap variabel dependen (IPM) dapat dijelaskan sebagai berikut:

1) Nilai sig. variabel $X_{1}$ menunjukkan nilai 0,000 . Nilai sig. lebih kecil dari profitabilitas 0,05 , atau $0,000<0,05$ artinya telah memenuhi kriteria tingkat signifikansi. Lalu nilai $\beta$ sebesar 32,022 menunjukkan adanya pengaruh positif. Dengan demikian $\mathrm{Ha}_{1}$ diterima. Variabel $\mathrm{X}_{1}$ yaitu Rasio Derajat Desentralisasi Fiskal berpengaruh positif signifikan terhadap IPM.

2) Nilai sig. variabel $X_{2}$ menunjukkan nilai 0,004 . Nilai sig. lebih kecil dari profitabilitas 0,05 , atau $0,004<0,05$ artinya telah memenuhi kriteria tingkat signifikansi. Lalu nilai $\beta$ sebesar 3,445 menunjukkan adanya pengaruh positif. Dengan demikian $\mathrm{Ha}_{2}$ diterima. Variabel $\mathrm{X}_{2}$ yaitu Rasio Efektivitas PAD berpengaruh positif signifikan terhadap IPM.

3) Nilai sig. variabel $X_{3}$ menunjukkan nilai 0,294. Nilai sig. lebih besar dari nilai profitabiltas 0,05 atau 0,294>0,05 maka $\mathrm{Ha}_{3}$ ditolak. Variabel $\mathrm{X}_{3}$ yaitu Rasio Belanja Modal tidak berpengaruh signifikan terhadap IPM.

Berdasarkan tabel 3 pula menunjukkan nilai $\mathrm{F}$ sig. kurang dari 0,05 yaitu 0,000 atau $0,000<0,05$; dan nilai $F_{\text {hitung }} 60,234>F_{\text {tabel }} 2,67$ sehingga memenuhi kriteria semua variabel independen secara simultan merupakan penjelas yang signifikan terhadap variabel dependen. Dengan demikian dapat dikatakan, Kinerja Keuangan Daerah yang diproksikan dengan Rasio Derajat Desentralisasi Fiskal, Rasio Efektivitas PAD, dan Rasio Belanja Modal secara simultan berpengaruh positif signifikan terhadap IPM.

Selanjutnya pada tabel 3 pula menunjukkan nilai adjusted R square sebesar $0,570=57,0 \%$. Nilai tersebut menunjukkan bahwa variabel independen Rasio Derajat Desentralisasi Fiskal, Rasio Efektivitas PAD, dan Rasio Belanja Modal memiliki kemampuan menjelaskan variasi variabel dependen yaitu IPM sebesar 57,0\%, sedangkan sisanya 43,0\% dijelaskan atau dipengaruhi oleh faktor lain di luar variabel penelitian yang digunakan. 


\section{PEMBAHASAN}

\section{Pengaruh Rasio Derajat Desentralisasi Fiskal terhadap IPM}

Rasio derajat desentralisasi fiskal menggambarkan proporsi partisipasi masyarakat di daerah dalam melaksanakan kewajibannya membayar pajak daerah dan/atau retribusi daerah, serta bagi hasil dari BUMD untuk menunjang pendapatan daerah secara keseluruhan. Semakin tinggi rasio derajat desentralisasi fiskal mengindikasikan semakin rendah ketergantungan pemerintah daerah terhadap sumber pendanaan dari pusat (Indramawan, 2018).

Berdasarkan hasil uji t parsial pada penelitian ini ditemukan bahwa rasio derajat desentralisasi fiskal berpengaruh positif dan signifikan terhadap IPM. Semakin tinggi rasio derajat desentralisasi fiskal, maka semakin tinggi pula IPM. Pemerintah daerah dianggap lebih mengetahui situasi, kondisi, dan kebutuhan setempat (Juliarini, 2019). Hasil pemungutan PAD dari partisipasi masyarakat dapat dimaksimalkan untuk meningkatkan pelayanan kepada publik sehingga kualitas hidup masyarakat, standar hidup layak, dan kesejahteraan masyarakat secara keseluruhan dapat ditingkatkan. Hasil penelitian ini mendukung hasil penelitian oleh Harliyani \& Haryadi (2016), Widyatama (2017), dan Hudaya (2019) yang menemukan bahwa rasio derajat desentralisasi fiskal berpengaruh positif terhadap IPM.

\section{Pengaruh Rasio Efektivitas PAD terhadap IPM}

Rasio efektivitas PAD menggambarkan derajat keberhasilan pemerintah daerah dalam merealisasikan target perolehan PAD. Keberhasilan pemerintah daerah pada penggalian potensi penerimaan secara mandiri dapat berimbas pada keleluasaan pemerintah daerah untuk menggunakan dana yang ada dalam rangka membangun dan mengembangkan perekonomian daerah. Perekonomian daerah yang meningkat dapat berdampak pada peningkatan standar hidup layak, kualitas hidup, dan kesejahteraan masyarakat.

Berdasarkan hasil uji $\mathrm{t}$ parsial pada penelitian ini ditemukan bahwa rasio efektivitas PAD berpengaruh positif signifikan terhadap IPM. Semakin tinggi rasio efektivitas PAD, maka semakin tinggi pula IPM. Ketersediaan dana dari perolehan lebih PAD dapat digunakan untuk banyak hal, diantaranya kebijakan menggratiskan biaya sekolah yang merupakan kebijakan yang berjalan di Jawa Barat. Imbas dari kebijakan ini yaitu pada pemerataan hak memperoleh pendidikan dan menjadi daya dukung yang luar biasa untuk meningkatkan IPM di Jawa Barat (Dianto, 2020). Hasil penelitian ini mendukung hasil penelitian oleh Prakoso (2017), Widyatama (2017), dan Hanif (2019) yang menemukan bahwa rasio efektivitas PAD berpengaruh positif terhadap IPM.

\section{Pengaruh Rasio Belanja Modal terhadap IPM}

Rasio belanja modal menggambarkan proporsi belanja yang dikeluarkan oleh pemerintah daerah untuk perolehan aset tetap atau aset lainnya yang diharapkan dapat digunakan untuk memaksimalkan pelayanan kepada publik sehingga dapat meningkatkan kualitas hidup, standar hidup layak, dan kesejahteraan masyarakat. Menurut Muda \& Naibaho (2018) terdapat dua jenis belanja modal, yaitu belanja modal yang pengadaannya dirasakan langsung oleh masyarakat, seperti untuk pembangunan jalan, rumah sakit, sekolah, dan seterusnya. Kedua, belanja modal yang pengadaannya tidak dirasakan langsung oleh masyarakat, yaitu belanja modal untuk menunjang operasional aparatur daerah atau negara, seperti untuk pembangunan gedung pemerintahan, kendaraan dinas operasional, dan seterusnya.

Berdasarkan hasil uji t parsial pada penelitian ini menemukan bahwa rasio belanja modal tidak berpengaruh signifikan terhadap IPM. Dengan kata lain, belanja modal yang dilakukan oleh pemerintah kabupaten/kota di Jawa Barat belum berkontribusi langsung terhadap peningkatan IPM. Dua diantara hal yang memungkinkan belum berkontribusi langsung belanja modal terhadap peningkatan IPM adalah pada besaran belanja modal dan ketepatan jenis belanja modal. Belanja modal seharusnya diarahkan untuk produktivitas (Aivanni, 2019). Belanja modal juga harus dipastikan menyentuh ke masyarakat atau tidak sekedar pengadaan (Setiaji, 2019). Belanja daerah seharusnya berkualitas, tepat waktu, memiliki dampak berganda, mampu mengurangi angka kemiskinan dan ketimpangan, serta dapat mendorong pertumbuhan ekonomi (Kristianus, 2019).

Hasil penelitian ini tidak mendukung penelitian oleh Sari \& Supadmi (2016), Umiyati et al. (2017), dan Tarumingkeng et al. (2019) yang menemukan bahwa rasio belanja modal berpengaruh 
positif signifikan terhadap IPM. Perlu peran wakil rakyat di daerah untuk mengarahkan belanja daerah pada sektor-sektor yang dapat meningkatkan IPM, seperti peningkatan pada fasilitas pendidikan, kesehatan, dan infrastruktur produktif.

\section{KESIMPULAN DAN SARAN}

Penelitian ini berupaya untuk menguji pengaruh kinerja keuangan daerah yang diproksikan dengan rasio derajat desentralisasi fiskal, rasio efektivitas PAD, dan rasio belanja modal terhadap IPM kabupaten/ kota di Jawa Barat. Dari hasil dan pembahasan pada bagian sebelumnya disimpulkan beberapa hal sebagai berikut:

1) Rasio Derajat Desentralisasi Fiskal berpengaruh positif signifikan terhadap IPM. Kemandirian keuangan daerah melalui hasil pemungutan PAD dari partisipasi masyarakat dapat dimaksimalkan untuk meningkatkan kualitas hidup masyarakat, standar hidup layak, dan kesejahteraan masyarakat.

2) Rasio Efektivitas PAD berpengaruh positif signifikan terhadap IPM. Ketersediaan dana dari capaian efektif dan perolehan lebih PAD dapat digunakan untuk memaksimalkan alokasi anggaran untuk meningkatkan kualitas SDM melalui pendidikan, kesehatan, dan ekonomi.

3) Rasio Belanja Modal tidak berpengaruh signifikan terhadap IPM. Belanja modal belum tepat sepenuhnya dari segi jenis. Belanja modal seharusnya diarahkan untuk produktivitas dan harus dipastikan menyentuh ke masyarakat atau tidak sekedar pengadaan.

Penelitian ini memiliki keterbatasan dengan belum mempertimbangkan secara rinci akan indikator- indikator utama dari IPM, yaitu indikator kesehatan, tingkat pendidikan, dan indikator ekonomi, dengan tiga dimensi dasar, yaitu umur panjang dan hidup sehat, pengetahuan, dan standar hidup layak. Penelitian berikutnya dapat mempertimbangkan untuk memperdalam pengujian dan pengkajian pada aspek tersebut.

\section{UCAPAN TERIMA KASIH}

Ucapan terima kasih disampaikan kepada pihak-pihak yang terlibat baik secara langsung maupun tidak langsung dalam penyelesaian penelitian ini. Ucapan terima kasih disampaikan kepada keluarga besar Program Studi S1 Akuntansi, Insitut Manajemen Wiyata Indonesia. Semoga semakin banyak kegiatan penelitian serta karya-karya publikasi penelitian yang dihasilkan di masa-masa berikutnya.

\section{DAFTAR PUSTAKA}

Aivanni, N. (2019). Alokasi Belanja Negara belum Tepat Sasaran. Mediaindonesia.Com. https://mediaindonesia.com/read/detail/252685-alokasi-belanja-negara-belum-tepat-sasaran

Asmara, C. G. (2019). Jokowi: Dunia Tak Semata Sedang Berubah Tapi Terdisrupsi. Cnbcindonesia.Com. https://www.cnbcindonesia.com/news/20190816104021-4-92446/jokowidunia-tak-semata-sedang- berubah-tapi-terdisrupsi

Dianto, T. (2020). Sekolah Gratis dan Imbasnya terhadap IPM. Kuninganmass.Com. https://kuninganmass.com/anything/netizen-mass/sekolah-gratis-dan-imbasnya-terhadap-ipm/

Hanif, M. I. (2019). Analisis Pengaruh Rasio Kemandirian dan Rasio Efektivitas Terhadap Indeks Pembangunan Manusia (IPM) dengan Pertumbuhan Ekonomi sebagai Variabel Intervening (Studi pada Kabupaten/Kota di Provinsi Jawa Tengah Periode 2013-2017). Universitas Islam Indonesia.

Harliyani, E. M., \& Haryadi, H. (2016). Pengaruh Kinerja Keuangan Pemerintah Daerah Terhadap Indeks Pembangunan Manusia di Provinsi Jambi. Jurnal Perspektif Pembiayaan Dan Pembangunan Daerah, 3(3), 129-140.

Hudaya, D. B. (2019). Pengaruh Rasio Keuangan Daerah terhadap Indeks Pembangunan Manusia 


\section{REKAN}

Riset Ekonomi, Akuntansi dan Perpajakan
Vol 1 No. 2 September 2020

e-ISSN : 2721-4109

(Studi Empiris pada Kabupaten/Kota di Provinsi Jawa Tengah Tahun 2012-2017). STIE YKPN.

Indramawan, D. (2018). Impacts of Financial Performance of Local Governments on Human Development Index in Papua. Simposium Nasional Keuangan Negara, 1(1), 1247-1272.

Juliarini, A. (2019). Kinerja Pendapatan Daerah Terhadap Indeks Pembangunan Manusia Studi Kasus Provinsi Di Pulau Jawa. Jurnal Good Governance, 15(1).

Kristianus, A. (2019). Bappenas: Belanja Pemerintah Belum Efektif Dongkrak Perekonomian. Investor.Id. https://investor.id/business/bappenas-belanja-pemerintah-belum-efektif-dongkrakperekonomian

Lidwina, A., \& Fitra, S. (2020). DKI Jakarta, Provinsi dengan Indeks Pembangunan Manusia 2019. https://databoks.katadata.co.id/datapublish/2020/02/19/dki-jakartapembangunan-manusia-tertinggi-2019

Databoks.Katadata.Co.Id. provinsi-dengan-indeks-

Mahmudi. (2016). Analisis Laporan Keuangan Pemerintah Daerah. UPP STIM YKPN.

Muda, I., \& Naibaho, R. (2018). Variables Influencing Allocation of Capital Expenditure in Indonesia. IOP Conference Series: Earth and Environmental Science, 126, 1315-1755.

Prakoso, L. I. (2017). Pengaruh Kinerja Keuangan Terhadap Indeks Pembangunan Manusia dengan Alokasi Belanja Modal Sebagai Variabel Moderasi di Kabupaten/Kota Se-Provinsi Lampung.

Sari, I., \& Supadmi, N. L. (2016). Pengaruh Pendapatan Asli Daerah Dan Belanja Modal Pada Peningkatan Indeks Pembangunan Manusia. E-Jurnal Akuntansi Universitas Udayana, 15(3), 2409-2438.

Setiaji, S. A. (2019). APBD Tidak Tepat Sasaran, Mendagri Tito Karnavian Akan Sisir Anggaran. Ekonomi.Bisnis.Com. https://ekonomi.bisnis.com/read/20191030/9/1164855/apbd-tidaktepat- sasaran-mendagri-tito-karnavian-akan-sisir-anggaran

Sugiarto, E. C. (2019). Pembangunan Sumber Daya Manusia (SDM) Menuju Indonesia Unggul.

Setneg.Go.Id.

https://www.setneg.go.id/baca/index/pembangunan_sumber_daya_manusia_sdm_menuju_indon esia_unggul

Tarumingkeng, W. A., Rumate, V. A., \& Rotinsulu, T. O. (2019). Pengaruh Belanja Modal dan Tingkat Kemiskinan Terhadap Indeks Pembangunan Manusia (IPM) di Provinsi Sulawesi Utara. Jurnal Pembangunan Ekonomi Dan Keuangan Daerah, 19(6).

Tusin, U., \& Hidayat, K. (2020). Indeks Pembangunan Manusia Indonesia tahun 2019 naik menjadi 71,92. Nasional.Kontan.Co.Id. https://nasional.kontan.co.id/news/indeks-pembangunanmanusia-indonesia- tahun-2019-naik-menjadi-7192

Umiyati, E., Amril, A., \& Zulfanetti, Z. (2017). Pengaruh Belanja Modal, Pertumbuhan Ekonomi dan Jumlah Penduduk Miskin terhadap Indeks Pembangunan Manusia di Kabupaten/kota Provinsi Jambi. Jurnal Sains Sosio Humaniora, 1(1), 29-37.

Widyatama, A. (2017). Pengaruh Rasio Keuangan Pemerintah Daerah Terhadap Indeks Pembangunan Manusia (Studi Empiris Pada Kabupaten/Kota di Provinsi Lampung). FEB Universitas Lampung.

Zulkarnain, Z. (2020). Analisis Rasio Keuangan Daerah untuk Mengukur Kinerja Keuangan Pemerintah Kabupaten/Kota di Jawa Barat. Cakrawala, 3(1), 61-74.

Zulkarnain, Z., \& Andriansyah, R. (2018). Opini Audit BPK-RI dan Substansi Kinerja Keuangan Pemerintah Daerah Kota/Kabupaten di Provinsi Kalimantan Barat. Cakrawala, 1(1), 58-74. 